\author{
非結晶粒子のコヒーレントX線回折イメージング \\ 中迫 雅由 ${ }^{1,2}$, 高山 裕貴 ${ }^{1,2}$, 苙口友隆 ${ }^{1,2}$, 白濱 圭也 ${ }^{1}$, 関口 優希 ${ }^{1,2}$, \\ 山本 雅貴 ${ }^{2}$, 米倉 功治 ${ }^{2}$, 引間 孝明 ${ }^{2}$, 眞木さおり ${ }^{2}$, 高橋 幸生 ${ }^{3,2}$, \\ 鈴木 明大 ${ }^{3,2}$, 松永 幸大 ${ }^{4}$, 加藤翔一 ${ }^{4}$, 星 貴彦 ${ }^{5}$ \\ 1慶應義塾大学 理工学部物理学科 ( ₹ 223-8522 神奈川県横浜市港北区日吉3-14-1) \\ 2理化学研究所 播磨研究所 放射光科学研究センター ( T 679-5148 兵庫県佐用郡佐用町光都1-1-1) \\ ${ }^{3}$ 大阪大学大学院 工学研究科精密科学・応用物理学専攻 (广5 565-0871 大阪府吹田市山田丘2-1) \\ ${ }^{4}$ 東京理科大学 理工学部応用生物科学科 ( $7278-8510$ 千葉県野田市山崎2641) \\ 5神津精機(株)（テ $215-8521$ 神奈川県川崎市麻生区栗木2-6-15）
}

\title{
Coherent X-Ray Diffraction Imaging of Non-Crystalline Particles
}

\author{
Masayoshi NAKASAKO,${ }^{1,2}$ Yuki TAKAYAMA, ${ }^{1,2}$ Tomotaka OROGUCHI,${ }^{1,2}$ \\ Keiya SHIRAHAMA, ${ }^{1}$ Yuki SEKIGUCHI,${ }^{1,2}$ Masaki YAMAMOTO, ${ }^{2}$ Koji YONEKURA, ${ }^{2}$ \\ Takaaki HIKIMA, ${ }^{2}$ Saori MAKI-YONEKURA, ${ }^{2}$ Yukio TAKAHASHI,${ }^{3,2}$ Akihiro SUZUKI, ${ }^{3,2}$ \\ Sachihiro MATSUNAGA, ${ }^{4}$ Shoichi KATO, ${ }^{4}$ and Takahiko $\mathrm{HOSHI}^{5}$ \\ ${ }^{1}$ Department of physics, Faculty of Science and Technology, Keio University \\ 3-14-1 Hiyoshi, Kohoku-ku, Yokohama, Kanangawa 223-8522 \\ ${ }^{2}$ RIKEN SPring-8 Center, RIKEN Harima Institute, 1-1-1 Kohto, Sayo, Sayo-gun, Hyogo 679-5148 \\ ${ }^{3}$ Department of Precision Science and Technology, Graduate School of Engineering, Osaka University \\ 2-1 Yamadaoka, Suita, Osaka 565-0871 \\ ${ }^{4}$ Department of Applied Biological Science, Faculty of Science and Technology, Tokyo University of Science \\ 2641 Yamazaki, Noda, Chiba 278-8510 \\ ${ }^{5}$ Kohzu Precision Co., Ltd., 2-6-15 Kurigi, Aso-ku, Kawasaki-shi, Kanagawa 215-8521
}

(Received May 10, 2012)

\begin{abstract}
Coherent X-ray diffraction imaging (CXDI) is a lens-less imaging technique that visualizes the structures of non-crystalline particles with micro- to sub-micrometer dimensions. In CXDI experiments, single spatially isolated particles are irradiated by X-ray beam with high transverse coherence. The projection images of the particles along the incident X-ray direction are then directly reconstructed from the diffraction amplitude using a phase retrieval algorithm. We recently developed a sample preparation system operated under a moisture controlled condition and a diffractometer to conduct cryogenic CXDI experiments at SPring-8 and the X-ray free electron laser (XFEL) facility called SACLA. Here we briefly introduce the theoretical background and show the preliminary experimental data from samples prepared by the humidity-control system collected with the diffractometer at BL29XU of SPring- 8 and the BL3 of SACLA.
\end{abstract}

Key Words: Coherent X-ray diffraction imaging, X-ray structure analysis, X-ray free electron laser, Non-crystalline particles, Image reconstruction

1. はじめに

物質に入射したX線は，主として，物質を構成する原 子の電子と相互作用する。 その結果生じる光電効果やコ ンプトン散乱などの非弾性散乱現象からは, 原子内電子 の運動量やエネルギー状態に関する情報が得られ, 弾性 散乱現象からは物質内電子の空間分布を知ることができ る、X線の弾性散乱理論によれば'，外部から入射する
$\AA(1 \AA=0.1 \mathrm{~nm})$ 波長のX線電場によって物質中の電子が 振動運動すると，入射X線と同じ波長のX線を放射(散 乱)する。多数の原子で構成された物質にX線平面波を 照射すると，あちらこちらの電子から散乱波が生じ，そ の足し合わせが干渉パターンとなって観測される (Fig. 1 (a)）。物質に強度 $I_{0}$ で波長 $\lambda$ の線を照射する場合，入射 伝播ベクトル $\vec{k}_{0}$ と観測方向伝播ベクトル $\vec{k}$ で定義される 散乱べクトル $\vec{S}(|\vec{S}|=2 \sin \theta / \lambda)$ でのX線強度 $I(\vec{S})$ は，X線照 
(a)

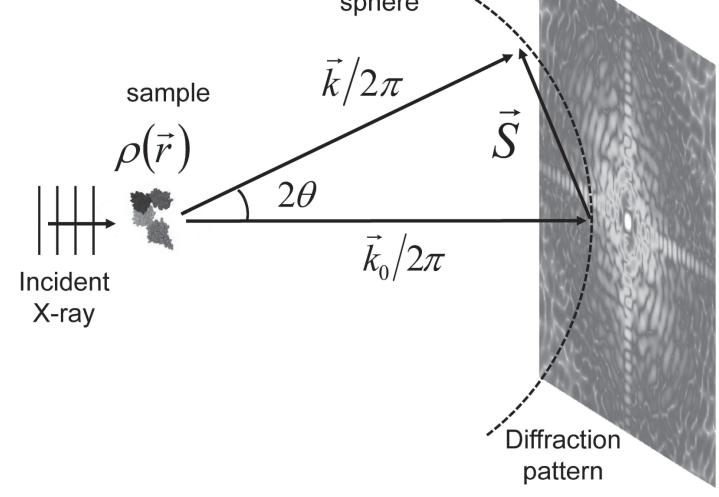

(b)

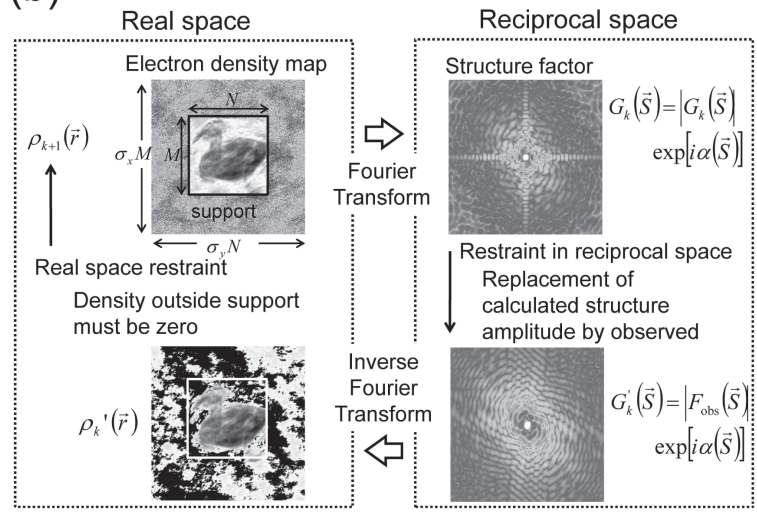

Fig. 1 Schematic illustrations of the coherent X-ray diffraction experiment (a) and the iterative phase-retrieval method (b).

射域の物質内電子密度分布 $\rho(\vec{r})$ のFourier変換である構造 因子 $F(\vec{S})$ とその複素共役の積で表わされる.

$$
\begin{aligned}
I(\vec{S})= & I_{0} r_{e}^{2}\left(\frac{\lambda}{\sigma A}\right)^{2} F(\vec{S})^{*} F(\vec{S}) \\
F(\vec{S}) & =\int \rho(\vec{r}) \exp (2 \pi i \vec{S} \cdot \vec{r}) d^{3} r=|F(\vec{S})| \exp [i \alpha(\vec{S})]
\end{aligned}
$$

ここで，Aは照射試料の大きさ， $\sigma$ はオーバーサンプリ ング比と呼ばれるパラメータ, そして, $r_{e}$ は古典電子半 径 $\left(2.8179 \times 10^{-15} \mathrm{~m}\right)$ である. 構造因子 $F(\vec{S})$ は複素数で 表わされ, その大きさ $|F(\vec{S})|$ を構造振幅, 偏角 $\alpha(\vec{S})$ を位 相と呼ぶ. $\alpha(\vec{S})$ は回折強度パターンから失われるので, 電子密度分布を構造因子の逆Fourier変換として得るに は，何らかの方法で $\alpha(\vec{S})$ を推定する必要がある $(\mathrm{X}$ 線構 造解析における位相問題 $)^{2)}$. 干渉パターンの幅や強さ には，物質内での電子密度分布情報がFourier変換の形で 刷り込まれるので, 物質内原子間距離 $(0.1 \mathrm{~nm})$ 程度の波 長をもつX線を用いれば，物質中の電子分布(原子配置) を知ることができる。ただし，入射X線によって生じる 電子からのX線放射確率 (散乱断面積) は, 古典電子半径 の自乗に比例するので極めて小さい，また，回折パター ンとして得られるのは，散乱べクトル空間の半径 $1 / \lambda$ の 反射球 (Ewald球) と交差する強度分布に限られる。実験
では，入射X線に対して粒子を回転させて，反射球と逆 空間強度分布との交差を変化させ，解析に必要な逆空間 強度分布を収集している。

立体構造未知の分子を結晶化すると，電子の散乱断面 積を十分補うことが可能なBragg回折現象が生じる ${ }^{1)} の$ で，有機分子から生体高分子まで，結晶状態にある分子 の構造が調べられてきた。1950年代からの構造解析の進 展は，より強力なX線光源を用いた解析の高効率化と高 度化を要求し，1960年代に回転対陰極X線発生装置， 1970年代には電子シンクロトロンを強力X線発生装置と する放射光施設，1990年代にはSPring-8に代表される大 型放射光施設が登場した。このような実験技術の進展に よって，巨大な生体分子やその複合体の原子解像度での 構造が次々と明らかにされるようになった2).

一方，結晶にならない，あるいは，できない物質のX 線構造解析は困難であるとされてきた。しかし，近年， 空間コヒーレンスの高いX線がSPring-8などで利用可能 になり，コヒーレントX線回折イメージング法(Coherent X-ray Diffraction Imaging: CXDI）による非結晶粒子の構 造解析に大きな進展があった ${ }^{3,4)}$ 。この構造解析方法の 原理が提示されたのは，1950年代であったが，高輝度軟 X線光源を用いて試験実験が可能となったのは，その約 半世紀後であった ${ }^{5)}$ 。 以来，高空間コヒーレンスX線 ビームが供給可能な放射光施設においては，同法がナノ 材料や生体内粒子などの構造研究に適用され始めてお $\eta^{6-9)}$, 今後, 細胞やオルガネラなどの多階層性機能空 間をより高い解像度で観察するための重要なツールにな ると期待されている。これまで，電子顕微鏡による細胞 切片観察がそのような構造研究に用いられてきたが，透 過性に優れたX線を用いることで，電子顕微鏡では困難 な対象丸ごとの観察が可能となる。例えば，ヒトの細胞

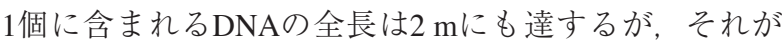
5-7 $\mu \mathrm{m}$ 程度の細胞核中にどのような形態で格納されてい るのかは依然不明である。CXDIによる核のnm分解能構 造解析は, DNAの核内格納形態をより鮮明に解き明か すであろう。

本稿では，CXDIについて，その原理，実験方法の現 状を䌕めるとともに，共用が開始されたX線自由電子 レーザー(X-ray Free Electron Laser: XFEL) 施設SACLA (SPring-8 Angstrom Compact Free Electron LAser) での初期 的な実験を紹介する。

\section{2. コヒーレントX線回折イメージング法の原理}

CXDIでは，高空間コヒーレンスX線ビームを空間に 孤立した試料粒子に照射し，高空間分解能検出器で回折 強度パターンを記録する。解析では，反復的位相回復 法 ${ }^{10)}$ と呼ばれるアルゴリズムにより，構造振幅のみか ら，入射X線方向に投影した粒子内電子密度を再生する (Fig. 1（b)）。そのため, 電子顕微鏡で問題となるレン ズ収差に煩わされることが無く，また，短波長X線の透 過性により，電子顕微鏡の適用範囲を超えた厚い試料の 内部構造を, 光学顕微鏡では到達不可能な分解能で可視 
化できる，本節では，X線回折振幅のみからのどのよう にして投影電子密度図が得られるのかを解説する。

簡単のため, 反射球が平面に近似できる場合を考え る. この時, 面検出器上に観測される構造振幅 $\left|F\left(S_{x}, S_{y}\right)\right|$ は, 試料粒子内電子密度分布 $\rho(\vec{r})$ を入射伝播ベクトル $\vec{k}_{0}$ 方向 (この場合, $z$ 方向)に投影した $\rho_{\mathrm{P}}(x, y)$ のFourier変換の 絶対值で与えられる。 $M \times N$ ピクセルの解像度で $\rho_{\mathrm{P}}(x, y)$ を再現するには, 回折パターンの各ピクセル位置につい て定められた連立方程式(2)の組みを解けばよい"11).

$$
\begin{aligned}
& \left|F\left(S_{x}, S_{y}\right)\right| \\
& =\left|\sum_{x=0}^{M-1} \sum_{y=0}^{N-1} \rho_{\mathrm{P}}(x, y) \exp \left[2 \pi i\left(S_{x} x / M+S_{y} y / N\right)\right]\right|
\end{aligned}
$$

しかし, 構造振幅 $\left|F\left(S_{x}, S_{y}\right)\right|$ をピクセル数 $M \times N$ で得ても, 回折強度分布の中心対称性(フリーデル則)のために方程 式数が半分となってしまう。これに対し, 回折パターン をより細かくサンプルして, $\sigma_{x} N \times \sigma_{y} M\left(\sigma_{x}, \sigma_{y}>1\right)$ ピクセ ルで構造振幅を観測する場合には， $\sigma_{x} \cdot \sigma_{y}>2$ あ゙あば (オーバーサンプリング $(\mathrm{OS})$ 条件) 中心対称性による情報 欠落を補って，原理的には方程式を解くことができる，

実際の解析では, OS条件下で得た $\left|F\left(S_{x}, S_{y}\right)\right|$ の組に対 して反復的位相回復アルゴリズム ${ }^{10)}$ を適用して $\rho_{\mathrm{P}}(x, y)$ を再生する (Fig. 1（b))。このアルゴリズムでは, 実空 間と逆空間を交互に行き来しながら，各過程で計算され た電子密度 $g(\vec{r})$ や構造振幅 $G(\vec{S})$ に制限を課す。逆空間 では，計算された構造因子 $G(\vec{S})$ の振幅を観測值に置き 換える。OS条件で得た構造因子を逆Fourier変換すると, 連立方程式が増えたことに対応して，実空間の $\sigma_{x} M \times \sigma_{y} N$ 領域に電子密度が現れる. 求めるべき構造は $M \times N$ 領域 (通常, サポートと呼ぶ) 内に現れ, その外の 電子密度は零である。このことを実空間での拘束条件と し, 解の収束判定にも用いる. 乱雑な電子密度から開始 しても，十分な $\mathrm{S} / \mathrm{N} て ゙$ 得た $\left|F\left(S_{x}, S_{y}\right)\right|$ から $\rho_{\mathrm{P}}(x, y)$ を回復で きる。

以上が, 最も簡単な入射伝播ベクトル方向への試料電 子密度投影図の回復方法である. 真空中試料粒子の三次 元密度分布を得る場合には, 要求される分解能でのOS 条件を満足するべく，粒子に様々な方向からX線を照射 して回折強度パターンを測定し, それらを統合・再構成 した構造振幅分布について三次元位相回復を行う ${ }^{11)}$. 実 際の実験では理想条件的測定デー夕の取得は困難である ため, X線照射による放射線損傷・破壊の問題を考慮し ながら実験をデザインする必要がある。また，試料性状 やX線回折に特有の理論的問題があるため, 地道な研究 がつづけられている。

CXDIの対象となる生体粒子や材料粒子の多くは, 水 溶液中で機能構造を保つ ${ }^{12)}$ 。溶媒包埋粒子にX線を入射 して得られる回折強度パターンには, 式(3)に示すよう に, 粒子 $F_{\text {part }}(\vec{S})$, 水領域 $F_{\text {water }}(\vec{S})$ の構造因子に加え, そ れらの干渉項が生じるため, 先述の真空内粒子に対する 解析方法を適用できない.

$$
\begin{aligned}
I(\vec{S}) & =I_{0} r_{e}^{2}\left(\frac{\lambda}{\sigma L}\right)^{2}\left[F_{\text {part }}(\vec{S})+F_{\text {water }}(\vec{S})\right]^{*} \cdot\left[F_{\text {part }}(\vec{S})+F_{\text {water }}(\vec{S})\right] \\
& =I_{0} r_{e}^{2}\left(\frac{\lambda}{\sigma L}\right)^{2}\left[\begin{array}{l}
F_{\text {part }}(\vec{S})^{2}+F_{\text {water }}(\vec{S})^{2} \\
+F_{\text {part }}^{*}(\vec{S}) F_{\text {water }}(\vec{S})+F_{\text {water }}^{*}(\vec{S}) F_{\text {part }}(\vec{S})
\end{array}\right]
\end{aligned}
$$

例えば，試料粒子一個を含む微小水滴コンテナでは， 粒子と液滴重心の相対関係を人為的に制御できず，式 (3)の干渉項の推定は不可能である。 これに対し, 我々 は, 生体粒子周辺に水が存在する試料からの回折パター ンから, 粒子の三次元電子密度を再構成可能な新たな解 析方法を考案し, その有効性を示した ${ }^{13)}$. その方法で は，まず位相回復によって実空間投影像を得て水領域の 電子密度を差し引き, 電子顕微鏡単粒子解析で開発され た三次元再構成法を援用して三次元電子密度分布を再生 する。ささらに, この方法を拡張し, ビームサイズ・強 度, 試料形態や検出器性能を反映させながら, 超分子複 合体の $\mathrm{nm}$ 分解能構造解析可能性の是非を議論できるよ うになった

回折角が大きい高分解能測定では，反射球面と交差す る回折強度分布のみが観測回折パターンに現れる ${ }^{1)}$ 。そ のため, 高分解能での像回復理論については, 反射球上 の回折強度分布と三次元電子密度の関係について, 二つ の物理数学面での問題を解決する必要がある。ひとつ は, 反射球上の回折振幅からその構造因子を導き出せる かという問題である。第二の問題は, 反射球上の構造因 子のFourier変換で得られる電子密度分布と実際の三次元 電子密度分布の関係を明らかにすることである，後者の 問題には解析解が存在するが, 前者については, 解析的 アプローチが困難であり，計算機に頼った解析が主とな る可能性が高い.

\section{3. コヒーレントX線回折イメージング実験用照射装置}

我々は, SPring-8 とSACLAの両方を相補的に活用した CXDIの展開を指向している。そのため, それら施設の 光源特性, ビームライン光学素子, 集光ビームサイズ, 測定試料粒子，照射野への試料導入方法や放射線損傷等 を考慮しながら，CXDI実験用照射装置を設計した．

SPring-8でのCXDI実験では, 試料上流に設置したピン ホールからのAiry Diskを試料に照射することを想定し た。この場合X線ビーム強度は $10^{8-9}$ photons/秒程度で, 低温X線タンパク質結晶構造解析での経験に基づけば, 試料を液体窒素温度に保持することで放射線損傷を十分 に低減でき，CXDIトモグラフィー実験が可能と考えら れた ${ }^{15)}$ 。一方，SACLAでの実験は，超強光子場による原 子レベルでの破壊的測定であると想定された。そのた め, 試料を順次照射野に投入し，10-100 Hz程度の周期 で飛来するX線パルスに対して歩留まりの高い照射を実 現することが不可欠とされた．

照射野への試料投入には，液滴や液体柱を粒子コンテ ナとする方法 ${ }^{16)}$, 電子顕微鏡での生体粒子水和凍結水包 埋法 ${ }^{17)}$ がある. 生体粒子の真空中室温下での実験は, 脱 
水しX線で損傷を受けた試料粒子を見ることになる可能 性が高いこと, 生体粒子の水和凍結水包埋法が歩留まり の高い照射を容易に実現できることなどから，両施設で 共通したスキームで実験操作が可能な水包埋法を採用す ることとした。 これにより, ガラス状水中や炭素薄膜上 に低温保持した希少試料粒子を照射野に投入することが できる，低温下では，真空中に水和凍結試料を設置で き，既に成熟した電子顕微鏡の技術を試料周りに転用す ることで，利用ユーザーの幅を広げるという利点もあっ た。筆者らはSPring-8でのタンパク質結晶の低温結晶解 析を先導してきたため ${ }^{18)}$, その延長線上にある技術の採 用に何の躊躇もなかったとも言える。

\section{4. コヒーレントX線回折イメージング用 クライオ試料固定照射装置 ${ }^{19}$}

我々はミクロン〜百ナノメートルサイズ非結晶粒子に 対するコヒーレントX線回折イメージング実験に向け て, “壽壱号”と命名した低温試料固定照射装置を開発し てきた。この装置では, 予め凍結固定し液体窒素中に保 存した試料粒子を, 液体窒素または液体へリウムで泠却 された試料台に搬送し，ゴニオメータで操作して照射実 験を行う。開発に当たっては, 蛋白質結晶に対する低温 $X$ 線回折実験技術 ${ }^{18)}$ 户湿度制御X線回折技術 ${ }^{20)}$ ，低温電 子顕微鏡の試料作製技術 ${ }^{17}$, 低温物理学での実験技術 ${ }^{21}$ などを援用した。

Fig. 2 (a) に壽壱号の全体像を示した。この一見風変 りな姿の装置は, 凍結試料を冷却しながらX線照射する ための液化ガス溜め(ポット)を真空槽中央に内蔵してい る(Fig. 2 (b)). ポットは外部真空ポンプに接続して負 圧下で使用し, 真空槽上部に搭載したクライオスタット からキュプロニッケル・キャピラリーを介して液体 $\mathrm{He}$ あるいは液体窒素が供給される。液体窒素を用いた場合 には66 Kに，液体Heを用いた場合は8 K以下に保たれ る.ポットは, 二段の断熱材料を介して室温動作ゴニオ メー夕に接続されて㧍り, 試料の並進 $(x, y, z$ 各軸のス トローク $3 \mathrm{~mm})$ と回転 $\left(-80 \sim+80^{\circ}\right)$ が可能である. 真 空槽内部は $10^{-5} \mathrm{~Pa}$ 程度に保たれる。

試料粒子は, $3 \mathrm{~mm}$ 外径の電子影微鏡用ピンホール板 に貼り付けた炭素薄膜上に湿度制御環境下で展開し, 液 体エタンを用いて急速凍結する。ピンホール板は, 液体 窒素中で専用ホルダーに固定され, 結露防止対策が施さ れた手動キャリアーと，掴み機構を持つ直線導入機ポッ トへ搬送される。ホルダー搬送を二連の小型ゲートバル ブと連動させており，ホルダー装填作業時の大気開放操 作は装置本体とローダー部真空に影響しない.

真空槽には，L字型のX線スリット二枚が組み込まれ て二次元Kratky光学系を構成し, 小角度領域に侵入する ビームライン上流からの妨害散乱を除去する。真空槽と 直線導入機は, 精密定盤に搭載され, 入射X線ビームに 対して位置調整が可能である。. 装置下流フランジには試 料位置を視認するための望遠鏡と検出器との間を結ぶ真 空パスが接続される.
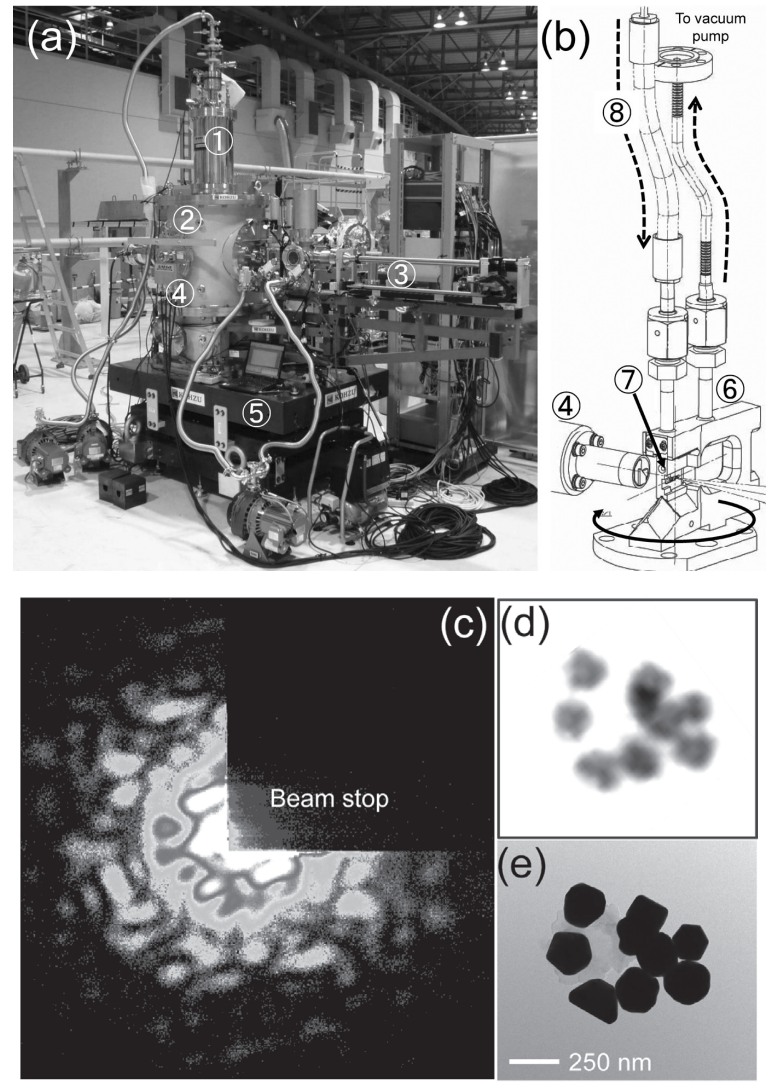

Fig. 2 (a) A photograph of the diffraction apparatus named KOTOBUKI ${ }^{19)}$ for coherent X-ray diffraction imaging experiments at cryogenic temperature (1: cryostat, 2: main vacuum chamber, 3: sample loading device, 4: silt system, 5: stage for alignment). (b) A schematic illustration of the cryogenic pot to maintain the sample temperature (6: pot for liquid nitrogen or liquid helium, 7: sample holder, 8: capillary tube from the cryostat). The dashed lines indicate the direction of gas flow. The outlet flexible tube is connected to vacuum pump installed outside the vacuum chamber. (c) The diffraction pattern of a cluster of 250-nm gold colloid particles collected at BL29XU. ${ }^{22)}$ (d) The projection image calculated at a resolution of $65 \mathrm{~nm}$ by a phase-retrieval algorithm from the diffraction pattern shown in (c). (e) An electron micrograph of the same gold cluster for comparison.

我々は，2009年11月～2011年11月の間にSPring-8 BL29XU ${ }^{22)}$ において4回の実機利用想定CXDI実験を実施し, ビーム ライン光学素子や装置機械要素の多数の動作軸制御, $X$ 線検出器やX線CCDカメラからの信号読み出しを1台の PCから実施可能なソフトウエア，試料装填操作用に特 化したタッチパネル方式の制御システムを完備した。装 置設置, 光学系調整, 試料作製, 試料装填, デー夕収 集，構造解析について豊富な経験が蓄積され，250 nm 金コロイド粒子集団 (Fig. 2 (c)-(e)), 燃料電池粒子, ミ トコンドリア，葉緑体 ${ }^{15}$ ，免疫系B細胞等のCXDI実験が 試みられた。金コロイド粒子集団の位相回復像は，電子 顕微鏡観察像と良く一致しており，1時間のX線照射に おいて振動や位置ドリフト無く露光が行えることを確認 
できた。また， $65 \mathrm{~nm}$ 分解能での位相回復像には，電子 顕微鏡では透過性の制限から観察できない粒子内部構造 を認めた。これらの結果を受け, 現在, BL29XUでは, 非結晶粒子CXDIに特化した実験ハッチの建設が進めら れている。

\section{5. 湿度制御環境下での試料作製 ${ }^{15,20)}$}

生体粒子のCXDI実験では, 生体粒子が水存在下で機 能発現すること及び放射線損傷が顕著であることから， 凍結水和状態での観察が不可欠である。これまでの CXDI分野では，二例を除いて ${ }^{22,23)}$ ，X線照射中に試料野 放射線損傷を低減する工夫が積極的になされておらず， 生体粒子であっても乾燥試料が用いられてきだ)。 た，現在の試料作製方法では粒子位置が不明で，実験時 の位置探索が不可欠となり，非効率的である。これらの 問題の解決には, 試料作成時の位置制御, 乾燥防止, 溶 媒量調節, 低温凍結といった技術を有機的に組み合わせ て余剩な水を含むことのない試料を作成するとともに, その固定位置を予め知っておく必要があった (Fig. 3 (a)).

CXDI実験に特化した試料作製のために，湿度制御槽 を独自に設計・製作した。この装置は湿度制御空気環境 下で，マイクロインジェクター付きマイクロマニピュ レーターによる試料操作を可能とする (Fig. 3 (b))。標 準的な試料作製では，マイクロインジェクターによる試 料粒子のキャピラリーへの吸引，ピンホール板上に張ら れたカーボン膜中心付近への吐出，余㮃水の湿度制御下 での蒸散(Fig. 3 (c)), 液体エ夕ン投下による粒子試料 の急速凍結である、SACLA実験では，高確率なX線照射 実現のため, 高濃度試料懸濁液を散布し(Fig. 3 (d)), 顕微鏡観察下で水分量調節後に急速凍結する.

開発した装置系を用いて，葉緑体 ${ }^{20)}$ ，ミトコンドリア やナノ材料粒子の凍結試料を作製し，CXDI実験に供し てきた。試料周囲の溶媒量調整による溶媒のX線吸収 · 散乱低減, 粒子位置探索の効率化, トモグラフィー実験 の簡単化等に関して，その有用性を確認できた。現在, この試料作製システムをさらに簢単に操作できるような 改良を検討しているところである.

\section{SACLAでのX線回折イメージング実験}

壽壱号照射装置は, SPring-8でのSACLA利用想定CXDI 実験を経て，2011年12月期からSACLAのBL3での調整 実験，2012年3月の共用実験へと歩を進めることとなっ た。ここでは, SACLAでの装置設置やアラインメント の概要と，共用実験で得られた幾つかの回折パターンを 紹介したい

壽壱号照射装置はBL3の実験ハッチに搬入して，X線 集光光学系 ${ }^{25)}$ の焦点に試料ホルダーの中心が位置するよ うに設置する。その下流には, 寄生散乱除去用の金属板 等の部品を組み込んだ真空パスを接続し, 最下流に octal-MPCCD検出器 ${ }^{26)}$, 極小角散乱領域の回折パターン を記録するためのsingle-MPCCD検出器が接続される (a)
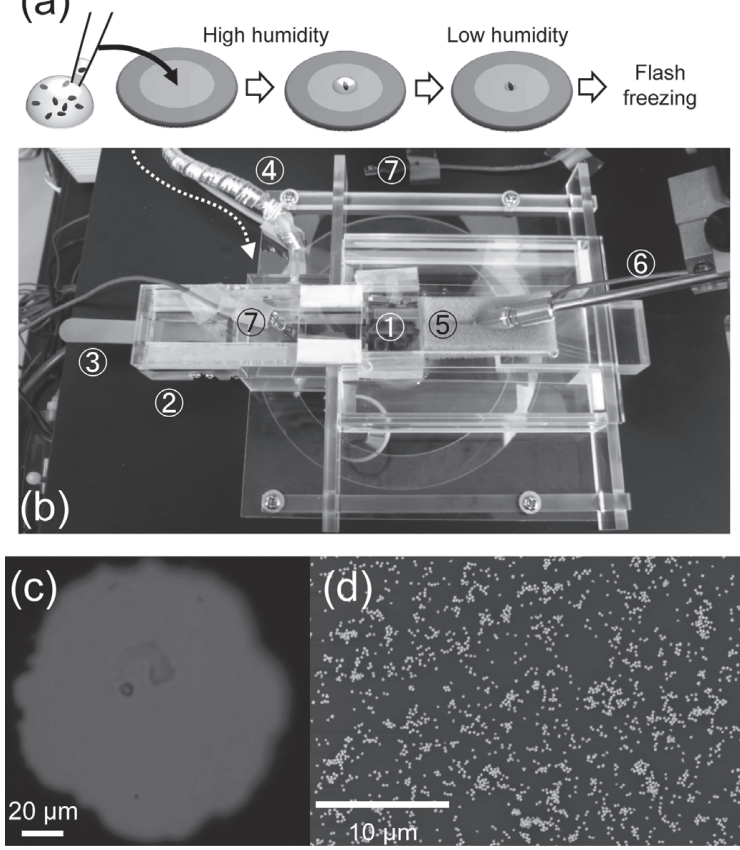

Fig. 3 (a) A schematic illustration showing the sample preparation procedure for CXDI experiments of non-crystalline particles under humidity-controlled conditions. In this scheme, samples are mounted on thin membrane covering the pinhole of a sample-mounting disk with the outer diameter of $3 \mathrm{~mm}$. (b) A view of the humidity-controlled sample-preparation chamber. The main chamber (1) acts as a platform and is filled by moist air from a humidity generator. The tweezers box (2) fixes a pair of tweezers (3), which holds a sample-mounting disk. Moist air passes through the tube (4). The two sponge plates (5) prevent the diffusion of moist air from the main chamber and enable the smooth movement of the microcapillary attached to the micro-manipulator (6). Two sensors were used to monitor humidity (7). (c) A optical microscopic view of an intact chloroplast particle from spinach prepared by using the device in panel (b). (d) A scanning electron microscopic view of a standard sample provided to the CXDI experiment at SACLA. The small dots are $250-\mathrm{nm}$ gold colloid particles on $\mathrm{SiN}$ membrane.

（Fig. 4）。壽壱号の設置位置は，2011年12月の調整実験 においてほぼ確定し，その位置をレーザー・トラッカー で記録してある。ハッチ内の移動がエア・パッドで行え ることもあり，レーザー・トラッカーを用いてビーム夕 イム毎の設置が容易に可能である。X線ビームの導入に 先立ち, 壽壱号照射装置と検出器の位置は, XFELビー ムと光軸を一にするHe-Neレーザー光を用いて調整され る。真空排気後にX線ビームを導入し，AlやSi製の減衰 板とYAG板を用いながらスリットや寄生散乱除去板等 の位置調整を行う。

湿度制御試料作製装置 ${ }^{15)}$ を用いて作製した試料は，ド ライ・シッパーを用いて輸送した。試料粒子はガラス状 水の中に水和凍結状態で保持されているので, 液滴・液 


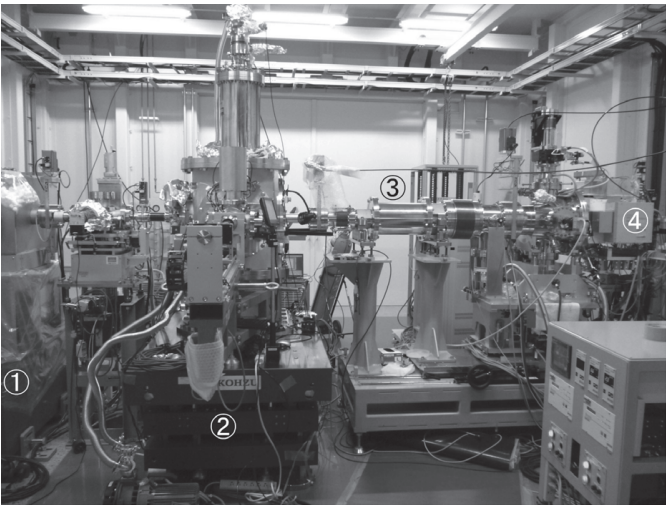

Fig. 4 A photograph of the apparatuses arranged for CXDI experiment in the BL3 hatch of SACLA. 1: focusing mirror system, ${ }^{25)} 2$ : the diffraction apparatus KOTOBUKI, ${ }^{19)}$ 3: vacuum path and 4: MP$\mathrm{CCD}$ detector. ${ }^{26)}$

体ビーム実験で問題となっている粒子安定化溶質の真空 中析出などの問題は生じない. 散乱断面積の大きな標準 粒子を溶液に懸濁後，湿度制御下で照射用試料作製を 行ってCXDI実験を行ったが，それら標準粒子形状から 予想される特徴を備えた回折パターンが得られている

(Fig. 5).

高濃度試料粒子懸濁液を吸着促進剂等で表面処理した カーボン薄膜等に散布した試料を(Fig. 3 (d))XFELパル スに同期させて並進動作させることで，20-60\%の確率 での試料粒子回折パターン取得を実現している。ちなみ に，スタンフォード大学のX線自由電子レーザー施設に おいて用いられている液滴ビーム装置では, 試料粒子へ の照射確率は5000ショットに1回程度である。これは, 同施設のX線ビーム位置が摇動すること, 液滴とX線 ビームのサイズミスマッチなどに起因している。

2012年3月に実施した共用実験では，パルス繰り返し 周期 $10 \mathrm{~Hz}$ でXFELビームエネルギー7 keVで加速器を運 転していただいた27)。このとき，1ショットのX線パル スの持つエネルギーは250 $\mu \mathrm{J} /$ pulse で，集光光学系焦点 (焦点サイズ $\left.1.2 \times 1.6 \mu \mathrm{m}^{2}\right)$ に集められたX線は，おおよ そ5 $\times 10^{10}$ photons $/ \mu \mathrm{m}^{2} / \mathrm{pulse}$ であったとの報告を受けてい る. 試料 - MPCCD検出器間距離は $2.2 \mathrm{~m}$ (分解能 $6.9 \mathrm{~nm}$ ) であり, 検出器pixel size $(50 \mu \mathrm{m})$ から, サイズ $1 \mu \mathrm{m}$ 試料 に対するOS比は約7であった。

試料にX線パルスを照射すると支持膜等を含め，全て が消失していた。これは, 超強光子場によって激烈な破 壊が生じたためと考えられる。しかし，Fig. 5に示すよ うな回折パターンが得られていることから, 試料破壊前 にThomson散乱が生じている(diffraction before destroy) と 考えるのが自然である. 装置および光学系の調整完了後 は, 試料交換しながら 24 時間の実験を継続すると, 回折 パターン画像 $(20 \mathrm{MB}$ /画像) を4Tバイト程度取得できる。

Fig. 5 (a)-(c)に単パルスで得た金属ナノ粒子の回折パ ターンを示す. Fig. 5 (a) は, 六角形状で直径約 $250 \mathrm{~nm}$ の金コロイド粒子が照射野に 2 個存在する場合のパター ンで, 大きなスペックルパターンは粒子の構造因子に,
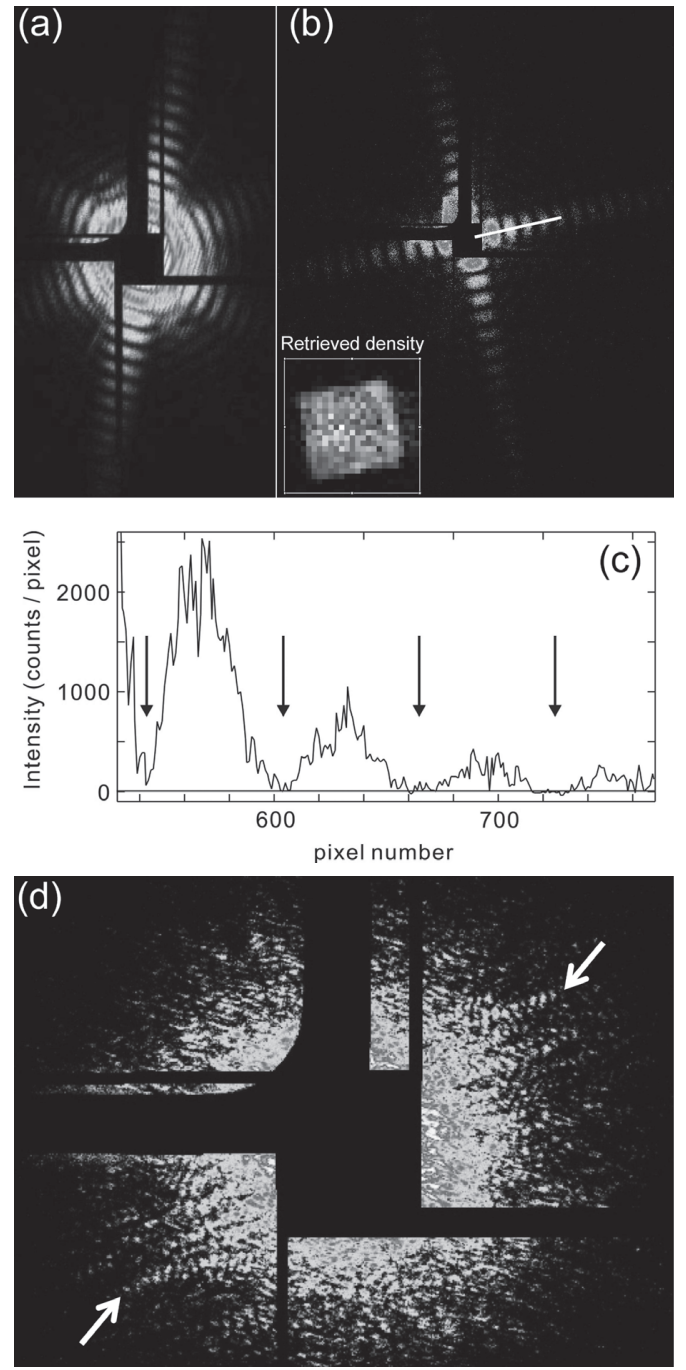

Fig. 5 Typical diffraction patterns from single particles with maximum dimensions of a micron or sub-micron obtained by a single-shot XFEL pulse of SACLA. (a) A diffraction pattern from two gold colloid particles with dimensions of approximately $250 \mathrm{~nm}$. The resolution of the upper edge corresponds to $14 \mathrm{~nm}$. (b) A diffraction pattern from single cubic shaped silver particle ${ }^{9)}$ with a dimension of $130 \mathrm{~nm}$. The resolution of the upper edge is $12 \mathrm{~nm}$. The inset shows a phase-retrieved image from the diffraction pattern at a resolution of $17 \mathrm{~nm}$. The line profile of the diffraction intensity along the white line is displayed in panel (c). The visibility estimated from this line profile indicates good transverse coherence of the focused XFEL beam. (d) A diffraction pattern from a frozen-hydrated single Cyanidioschyzon merolae, ${ }^{28)}$ which is the smallest eukaryote in the earth (approximately 1 micron). The arrows indicate a pair of speckle patterns showing a good Friedel relation at a resolution of $43 \mathrm{~nm}$.

また, 細かな縞模様は二粒子からの回折波の干渉に由来 する. 銀キューブ粒子 ${ }^{9)}$ からの回折パターン (Fig. 5 (b)) は矩形開口からの回折強度関数で良く近似でき, CXDI 実験の標準試料として位置付けている。図の左下には, 位相回復した $17 \mathrm{~nm}$ 分解能での粒子像を示した。回折パ 
ターンのラインプロファイル (Fig. 5 (c))では, visibility が1に近く，集光XFELビームがほぼ完全な空間コヒーレ ンスを持つと考えられた。

Fig. 5 (d) は, 単細胞生物シゾンの回折パターンであ る。試料は, 東京理科大学で培養したものを $40{ }^{\circ} \mathrm{Cに}$ 保って慶應義塾大学まで運び，そこで湿度環境制御しな がら凍結した。粒子濃度を高めたことにより，10 Hz照 射での試料粒子へのヒット率は約 $65 \%$ であった。高空間 コヒーレンスを反映して，回折パターンには良好な Friedel則を見ることができる，今後，極小角領域を十分 なダイナミックレンジで測定すれば，シゾン 1 個体の投 影電子密度分布を $17 \mathrm{~nm}$ 程度の分解能で明らかにできる のではないかと期待している。

\section{7. おわりに}

このように，壽壱号は順調な船出をした，我々は，今 後, 実験や解析手順を一般ユーザー利用に向けて簡単化 する方法を模索し， SACLAとSPring-8を相補的に利用す るCXDI実験を行いながら, 生命科学・材料科学分野で見 出されている非結晶粒子の高分解能構造解析を推進した いと考えている，そこでは，光学顕微鏡，電子顕微鏡， 原子間力顕微鏡, 核磁気共鳴イメージング等の他の技術 と深く連携しながら, SACLA-SPring-8のCXDIの立ち位 置とイメージングでの役割を明確にし，新たなイメージ ング実験のパラダイムを目指したいと考えている.

\section{謝 辞}

装置製作で御助力いただいている神津精機(株)の 竹内 尊利氏，仁木工芸(株)の故鈴木 朝雄氏，西晃司氏， (株)理学相原精機の鳥塚康史氏に謝意を表します。

実験におきましては，SPring-8のBL29XUを担当する 香村 芳樹博士, SACLA検出器グループの亀島 敬博士, 桐原陽一博士, 小野峻博士, 初井 宇記博士, SACLA ビームライングループの矢橋 牧名博士, 登野健介博士, 犬伏雄一博士， SACLAエンジニアリングサポートチー ムの金徹坤氏，藤原 嘉朗氏らに御助力頂きました。

本稿に記した装置開発と実験には，文部科学省XFEL 利用推進課題研究, 特定領域研究, 新学術領域研究, 日 本学術振興会の基盤研究 (A), 挑戦的萌芽研究, およ び, 理化学研究所からのSACLA利用装置提案課題の支 援を受けました。実験は, SPring-8理研ビームライン利 用課題(課題番号20090097，20100035，20110006)および SACLA利用研究課題(課題番号2012A8001，2012A8005, 2012A8022)として実施されました。

\section{参考文献}

1) 三宅 静雄：X線の回折(朝倉書店, 1969)

2) 中迫 雅由：タンパク質科学 - 構造・物性・機能(化学同人, 2005) p.32.

3) J. Miao, T. Ishikawa, Q. Shen, and T. Earnest: Annu. Rev. Phys. Chem. 59 (2008) 387.

4) J. Miao, D. Sayre, and H. N. Chapman: J. Opt. Soc. Am. A 15 (1998) 1662

5) J. Miao, P. Charalambous, J. Kirz, and D. Sayre: Nature 400 (1999) 342.

6) C. Song, H. Jiang, A. Mancuso, B. Amirbekian, L. Peng, R. Sun, S. S. Shah, Z. H. Zhou, T. Ishikawa, and J. Miao: Phys. Rev. Lett. 101 (2008) 158101.

7) Y. Nishino, Y. Takahashi, N. Imamoto, T. Ishikawa, and K. Maeshima: Phys. Rev. Lett. 102 (2009) 018101.

8) H. Jiang, C. Song, C.-C. Chen, R. Xu, K. S. Raines, B. P. Fahimian, C.-H. Lu, T.-K. Lee, A. Nakashima, J. Urano, T. Ishikawa, F. Tamanoi, and J. Miao: Proc. Natl. Acad. Sci. USA 107 (2010) 11234

9) Y. Takahashi, Y. Nishino, R. Tsutsumi, H. Kubo, H. Furukawa, H. Mimura, S. Matsuyama, N. Zettsu, E. Matsubara, T. Ishikawa, and K. Yamauchi: Phys. Rev. B 80 (2009) 054103.

10) J. R. Fienup: Appl. Opt. 21 (1982) 2758

11) J. Miao, K. O. Hodgson, and D. Sayre: Proc. Natl. Acad. Sci. USA 98 (2001) 6641

12) M. Nakasako: Phil. Trans. Roy. Soc. Lond. B 359 (2004) 1191.

13) W. Kodama and M. Nakasako: Phys. Rev. E 84 (2011) 21902.

14）苙口友隆, 中迫 雅由: 第25回日本放射光学会年会・放射 光科学合同シンポジウム予稿集(2012年1月) 8P126.

15) Y. Takayama and M. Nakasako: Rev. Sci. Instrum. 83 (2012) 054301.

16) M. M. Seibert, T. Ekeberg, F. R. N. C. Maia, M. Svenda, J. Andreasson, O. Jönsson, D. Odić, B. Iwan, A. Rocker, D. Westphal, et al.: Nature 470 (2011) 78.

17) A. W. Robards and U. B. Sleytr: Low Temperature Methods in Biological Electron Microscopy (Elsevier, Amsterdam, 1991).

18) 中迫雅由：タンパク質の結晶化(京都大学学術出版会, 2005) p.267.

19) 中迫雅由, 山本雅貴：生物物理 51 (2011) 278.

20) Y. Takayama and M. Nakasako: Biophys. Chem. 159 (2011) 237.

21）小林 俊一, 大塚 洋一：物理工学実験7 低温技術 [第二版] (東京大学出版会, 1987).

22) K. Tamasaku, Y. Tanaka, M. Yabashi, H. Yamazaki, N Kawamura, M. Suzuki, and T. Ishikawa: Nucl. Instrum. Meth. A 467-468 (2001) 686

23) X. Huang, J. Nelson, J. Kirz, E. Lima, S. Marchesini, H. Miao, A. M. Neiman, D. Shapiro, J. Steinbrener, A. Stewart, J. J. Turner, and C. Jacobsen: Phys. Rev. Lett. 103 (2009) 198101.

24) E. Lima, L. Wiegart, P. Pernot, M. Howells, J. Timmins, F. Zontone, and A. Madsen: Phys. Rev. Lett. 103 (2009) 198102.

25）三村 秀和, 湯本 博勝, 小山貴久, 大橋治彦, 石川哲也, 山内 和人：日本放射光学会誌 25 (2012) 76.

26) 初井宇記, 亀島敬, 小野峻, 桐原陽一, 工藤統吾, 小林和生, 遠茂谷誠彦, 尾崎恭介, 城地保昌, 徳久 淳師, 堀米利夫, 山鹿光裕, 古川行人, 清道明男, 杉本崇, 広野等子, 大端通, A. Amselem, 田中良太郎： 日本放射光学会誌 25 (2012) 82 .

27）田中均, 原徹, 渡川和晃, 田中隆次, 矢橋牧名：日本 放射光学会誌 25 (2012) 89.

28) M. Born and E. Wolf：光学の原理(東海大学出版会, 1974) 第 $\mathrm{X}$ 章

29）黑岩 常祥：蛋白質・核酸・酵素 50（2005）97. 